\section{Menstrüasyon ve tabu}

\section{Berivan Vargün ${ }^{1 *}$}

'Dr. Öğr. Üyesi| Ardahan Üniversitesi, Sosyoloji Bölümü, Ardahan - Türkiye

Alındı/Received: 15 Nisan / April 2019| Düzeltildi/Revised: 12 Kasım / November 2021 Kabul/Accepted: 9 Aralık / December 2021 | Yayımlandı/Published: 28 Aralık / December 2021

\section{Öz}

Kadınların günlük yaşam aktivitelerini ve pratiklerini derinden etkileyen konulardan biri menstrüasyondur. Menstrüasyon hem biyolojik hem de sosyal etkileri olan ve özellikle geleneksel uygulamaların sergilendiği toplumlarda kültürel şartlanma ve değerler çerçevesinde yaşanılan bir süreçtir. Menstrüasyon kadınların yaşamını etkileyen önemli bir konu olmakla birlikte, kimi kültürlerde sadece kadını ilgilendiren bir konu değil, aynı zamanda kültürel örgütlenme içinde ifade edilen, kaçınma, sakınma ve mahcubiyet rolleri ile çerçevelenen ve bu rollere göre davranışların geliştirildiği de bir konudur. Bu makalede Menstrüasyon dönemine ilişkin tabu olarak yorumlayabileceğimiz sakınma, kaçınma, koruma ve korunmaya yönelik uygulamalar değerlendirilmektedir. Bu uygulamalara ilişkin örnekler, görüşme yaptı̆̆ımız kişiler tarafından aktarılmıştır. Alan araştırmasına dayalı çalışmamız, 2016 yılında Şanlıurfa'nın Bozova, Eyyübiye ve Harran ilçelerinde, yaşları 18-73 arasında değişmekte olan 68 kadınla gerçekleştirilmiştir.

Anahtar sözcükler: Tabu, menstrüasyon, kadın, toplumsal cinsiyet

\section{Giriş}

Hem biyolojik hem kültürel bir olgu olan menstrüasyon özellikle geleneksel uygulamaların sergilendiği toplumlarda kadınların gündelik yaşam pratiklerini ve gündelik yaşamı organize etme biçimlerini etkilemektedir. Menstrüasyon, kültürel șartlanma ve değerler çerçevesinde yașanan bir süreçtir. Menstrüasyon kadınların yaşamını etkileyen önemli bir konu olmakla birlikte, kimi kültürlerde sadece kadını ilgilendiren bir konu değil, aynı zamanda kültürel örgütlenme içinde ifade edilen, kaçınma, sakınma ve mahcubiyet rolleri ile çerçevelenen ve bu rollere göre davranışların geliştirildiği de bir konudur.

Pek çok kültürde menstrüasyon ve bu döneme ilișkin çeșitli tabuların var olduğu bilinmektedir. Genel olarak tabu, "ritüel sınırlama ve yasaklama anlamına gelmektedir (Gould ve Kolb, 1964, s. 714). Tabu kelimesi, Polinezya diline ait bir sözcüktür. Kaptan James Cook'un Pasifik Okyanusu'na yaptığı son yolculuğunda, Polinezya'da karşlaş̧ı̆̆ı bu terim, Avrupa dillerine "yasaklanan şey", "yasak" ya da "kutsal"

\section{Menstruation and taboo \\ Abstract}

One of the issues influencing women's Daily activities deeply is menstruation. Menstruation is a process having both biological and social impacts and experienced with cultural conditioning and within the framework of values. Although it is one of the important issues affecting women's lives, it is an issue which concerns women, but it is also an issue expressed in cultural organisation, framed by such roles as avoidance, refrainment and embarrassment and behaviours are developed according to those roles in some cultures. This paper considers avoidance, refrainment and protection practices, which can be interpreted as taboos about menstrual period. Several applications, beliefs and practices have developed in the districts in relation to avoidance, refrainment and protection about the process of menstruation. Examples for the practices and the practices developed were reported by the participants interviewed. This study, which is based on field research, was conducted with 68 women who were aged between 18 and 73 in 2016 in Bozova, Eyyübiye and Harran districts of Şanluurfa.

Key words: Taboo, menstruation, woman, gender

olarak uyarlanmıștır (Gould ve Kolb, 1964, s. 714). Tabunun Polinezya dilindeki zıttı "noa" sözcügüüür ki noa "siradan, yanaşılabilit, tutulabilit" demektir. Eski Romalılar'’n kullandığ1 "sacer", Eski Yunanlılar'tn kullandığ "agov" sözcükleri Polinezyalıların tabusuna karşılık gelir. Amerika, Afrika (Madagaskar), Kuzey ve Orta Asya kavimlerinde de "tabu" anlamina gelen kelimeler vardır (Freud, 2014, s. 35). Tabu, yasaklar koyma sistemidir ve bir toplumda belirli eylem ve sözler üzerindeki kısıtlamalardır. Bu yasaklar söz konusu eylem veya sözlerin normlar dahilinde kabul edilemez olduğunu belirtmek için kullanullir. Tabu olan şey konuşulmamalı ve uygulanmamalıdır. Kaçınma dereceleri bir sosyal bağlamdan diğerine değişir (Agyekum, 2002, s. 370).

Leach, tabunun, dinsel, sosyal yasaklamalar ve emirler sistemi olduğunu vurgular. Tabular, yer, kişi, nesne, isim tabularr olabilir ya da dokunmama, anmama, söylememe, yapmama gibi belli eylemler üzerinde yoğunlaşır. Tabu; tabu olan şeyin kutsal olduğu, doğal bir gizil güce sahip olduğu, doğaüstü güçlerle ilişkisi 
olduğu ve bu nedenle gizil bir güç kazandığı, temiz olmadığ1 (belli yiyecekler, hasta insanlar, suçlular, ölüler, vb.), sonucu etkileyeceği (doğum, evlilik, seksüel fonksiyonlar, vb.) ya da hirsızlıktan, tecavüzden, zarardan korunması gerektiği gibi düşüncelerden kaynaklanır. Tabuyu yıkanların hastalıkla ya da ölümle karşılaşacağına inanilir (Leach, 1972, s. 1098).

Tabu, tehlikeli durumlarda özel ve kısıtlayıc1 davranışlarlailintilidir,bunedenletopluluküyeleritabudan kaçınma davranışları gösterirler. Günümüz modern dünyasinda tabu, hem antropolojik araştırmalarda totemizmle yakın ilişkisi olan yasaklamaları hem de daha genel anlamda dinsel, ahlâki, toplumsal ve kültürel alandaki güçlü yasakları ifade eder (Yolcu, 2014, s. 6869). Freud (2014), tabu sinırlamalarının din ya da ahlâkî yasaklardan farklı olduğunu vurgular. Tabu yasakları, doğrulukları için akla uygun hiçbir neden göstermezler, kökenleri belli değildir, anlaşılmazlar ama boyunduruğu altında yaşayan kişiler için bu yasaklar bir zorunluluk, bir gerçek olarak kabul edilir (2014, s. 35-36).

"Tabular ya süreklidir ya da belli bir süre için geçerlidir" (Örnek, 1995, s. 34). Frazer, sürekli ve geçici tabulardan bahseder. Sürekli tabular, rahipleri, başkanları, ölüleri ve bunlarla ilgili her şeyi kapsar. Kadınların aybaşı durumu ve lohusalığı, bir savaşçının sefere ya da bir avcının ava çıkmadan ve çıktıktan sonraki durumu gibi durumlarsa geçici tabudur (Frazer'dan akt. Freud, 2014, s. 38). Frazer'ın geçici tabular arasında nitelediği menstrüasyon dönemi, birçok toplumda kadınlardan sakınmayı, kaçınmayı hatta onların inzivada bulunmalarını gerektiren bir süreç olarak algılanır ve bu çerçevede çeşitli ritüeller gerçekleştirilir. Papua Yeni Gine'deki Kafe toplumunda, ilk menstrüasyonunu gören k1z çocuğu bir hafta kadar evinden çıkartılmaz ve sadece ateşte pişirilmiş tatlı patates yemesine izin verilirken, su içmesine ve şeker kamışı yemesine izin verilmez. Kendi yaşıtlarından oluşan bir grup kızla birlikte karanlık bir kulübede oturur ve yaşlı kadınların verdiği öğütleri ve talimatları dinlerler. Menstrüasyonunu gören kıza, her ay hâlinde gelen kanın ne kadar tehlikeli olduğu, bu nedenle kendini temizlerken kullandığı kumaş ve yaprakları düzgün bir şekilde atması gerektiği anlatılır. Aynı toplumda menstrüasyon dönemindeki evli kadın, periyotlarını geçirmesi için kocası ve akrabalarının inşa ettikleri özel bir kulübede kalır, arkadaşları ve akrabalarının getirdiği yiyeceklerle beslenir, daha sonra aynısını arkadaşları için yapması da kadından beklenir (Faithorn, 2014, s. 144-145).

Underhill'in (2003) çalışmasında bahsettiği Papago'lu ${ }^{1}$ bir genç kızın anlatıları, inzivaya çekilmenin ve bu durumu içselleştirmenin önemli bir göstergesidir:

Neredeyse annemin boyuna ulaştığımda, bütün

${ }^{1}$ Arizona çöllerinde yaşayan bir Amerikan yerli kabilesi kadınların başına gelen şey benin de başıma geldi. Ama beyaz insanların başına da aynı şeyin gelip gelmediğinden tam olarak emin değilim. Biz buna âdet görmek deriz. Genç kızlar bu dönemde çok tehlikeli olurlar. Bir erkeğin yayına dokunurlarsa ya da bakarlarsa, o yay artık atış yapamaz hale gelir. Bir erkeğin kullandığ tastan içerlerse, o adam hasta olur. Adamin kendisine dokunurlarsa, adam düşüp ölebilir. Annem çok uzun süre önce bize bunlardan söz etmişti, köyümüzde neler olduğunu hepimiz biliyorduk. (s. 129-130)

Genç kız, kutsal duruma saygisızlıkta bulunursa, sadece kendisinin değil, ailesinden kişilerin de cezalandırılacağına ve öleceğine inanmaktadır:

İşte bu yüzden, eğer herhangi bir köye yıldırım düşerse, hangi kadının tehlikeli olduğunu anlamak için büyücü çağırırlar. Büyücü genç kızların hepsini yanına çağırtır, kimin saygısızlık ettiğini öğrenmek için kristallerine bakar. Kadını bulduklarında onu cezalandırmazlar. Bu kadının, dostlarını öldürdüğ̈nün bilinmesi yeterince ağır bir cezadır. Ay hali boyunca dört gün "küçük evde" (menstrüasyon dönemindeki kadınlar için, asıl barınağın yanında yapılmış, bir kişinin uzanıp yatabileceği büyüklükteki yer) kalan genç kız, dört günün sonunda annesi tarafindan y1kanarak asıl barınağa götürülür; büyük tehlike geçmiştir ama bir dört gün daha kız saçını kaşımak gibi belli eylemleri yapmaktan kaçınır. (Underhill, 2003, s. 132-133)

Çeşitli toplumlarda aybaşı hâlindeki kadının, kirli ve tehlikeli olduğuna inanılır. Örnek (1995), kimi tabuların pislik düşüncesinden kaynaklandığını vurgular. "Ay hâlindeki kadınlar" çoğu zaman başkalarıyla yemek yemezler, belli birtakım yiyeceklere dokunmaktan kaçınırlar ayrıca kendileri için inşa edilen özel kulübelerde kalırlar ve erkeklerle cinsel ilişkide bulunmazlar. Aybaş1 kulübesinin bulunmadığ yerlerde evin ya da odanın bir kısmı hasır örtülerle bölünür. Burada kalan kız, tüm bu kaçınmaların yanı sıra sık sık yıkanır, tütsülenir ve bedenini boyar (Örnek, 1995, s. 37). Kirlilikle ilgili 
korkuların kaynağında bir yasağı bilinçsizce delenlerin ya da murdar bir duruma yol açanların başına korkunç felaketler geleceğine dair inançlar vardır. Kirlenme esas olarak düzensizliğe eş değerdir ve kirlilik var olan düzeni tehdit eder. Kirlilikle ilgili inançlar incelendikçe tehlikeli olduğu düşünülen temasların aynı zamanda sembolik bir anlam da taşıdığı ortaya çıkar (Douglas, 2017, s. 23-26).

Band ve köy toplumları, kadınları, aybaşı hâli sırasında kirli sayarlar. Onlar âdet kanına kirletici olarak bakarlar (Harris, 1994, s. 93). Pasifiğin büyük Namba toplumunda aybaşı döneminde kadınlardan zehirli ve kirli kan geldiğine inanılmaktadır. Bedendeki kötülüklerin kirli kanla atılacağına inanılır bu nedenle aybaşı dönemindeki kadınların toplumdan uzak kalmasına dikkat edilir. Arapesh toplumunda periyod ve doğum kanı tehlikelidir ve köy için sakıncalı olduğuna inanılır. Kadınların doğum ve periyod dönemleri için çadırlar (menstrual hut) inşa edilir. Yanomamölerde, kızlar ilk aybaşılarında evlerine hapsedilirler ve yapraklardan bir paravanın ardına saklanırlar (Chagnon'dan akt. Türk ve Avşar, 2008, s. 49-51). Amerika'nın güneybatı sahilinde yaşayan kabilelerde (Pueblolar hariç), aybaşı geçiren kadın kendisi için ayrılan küçük evlere kapatılır. Yemek için ayrılan tabakları bile tümüyle diğgerlerinden farklıdır, ev içindeki ilişkileri sınırlıdır, eğer bir avcının silahına bu dönemde dokunursa o silah yok edilir (Benedict'ten akt. Türk ve Avşar, 2008, s. 51).

Menstrüasyon dönemindeki kadin bitki dikmemelidir, dikse bile yaşamaz. Menstrüasyon dönemindeki bir kadın bitkileri sulamamalıdır. Eğer menstrüasyon dönemindeki bir kadın bir bitkiye dokunursa, bitki solar. Menstrüasyon dönemindeki bir kadın kirli olduğu için bitkilere dokunmamalıdır, yoksa bitki ölür (Hand vd., 1981, s. 1370). "Menstrüasyon dönemindeki bir kadın barındığı yerden ayrılmamalıdır / ekili araziye yaklaşmamalıdır, yoksa ürünler mahvolur / hayvan barınağına girmemelidir / suya girmemelidir / menstrüasyon kanını toprağa damlatarak toprağ1 kirletmemelidir" (Thompson, 1966, s. 501). "Menstrüasyon dönemindeki bir kadının elinden yiyecek yenilmez" (Thompson, 1966, s. 509). "Menstrüasyon dönemindeki kadın, pişirme kaplarına ve kocasının eşyalarına dokunmamalıdır" (Thompson, 1966, s. 521). Nusayrî inancinda âdetli kadınlar asla Hirisi'ye yaklaşamaz. Namaz kilanlara verilecek yemeklerin hiçbirine âdetli kadınlar dokunamaz. Aybaşı olan kadın bayram ve adaklarda kullanılacak tencere, tava gibi eşyaya dokunamaz, mutlaka temiz bir insanın dokunması gerekir. Eğer bayram türbe yanında yapıllyorsa ve âdetli bayanlar buraya gelmişse, türbenin yanında bulunan su kaynağ1 kurur. Yemek pişmez (Türk, 2013, s. 190-191).

Âdet kirliliği inançları iki karmaşık alanı ifade eder. Kimi toplumlarda menstrüasyona ilişkin kirlilik inançları, zehirle ilgili olan tehlike inançları gibi değerlendirilirken kimi toplumlarda ise kirliliğe ilişkin inançlarla eş değerdir. Menstrual kirlilik inançlarının içinde bir dizi tezat ve tamamlayıcı öğelerin görüldüğü bağlamlar vardır. Papua Yeni Gine Mt. Hagen'de âdet kirliliği ile yemek pişirme ve zehir arasında belirgin bir ilişki kurulur. Menstrüasyon kanının kötü bir kokusu vardır, menstrüasyon sürecindeki kadın tarafindan yapılan yemekte kötü bir koku olur. Bu erkekler için tehlikeli ve kirleticidir aynı zamanda hastalıklara ve ölüme sebep olur. (Hage ve Harary, 1981, s. $367-$ 369). Menstrüasyon doğal bir vücut fonksiyonudur ve geçmişten bugüne, çeşitli tabuların ve ritüellerin nesnesi olmuştur. Menstrüasyonla ilgili efsanevi hikayeler, âdet kanını kutsal, tanrilardan bir hediye veya bir ceza olarak çeşitli şekillerde karakterize eder ve bu kan neredeyse her zaman büyülü ve güçlüdür bu nedenle menstrüasyonlu kadinlar tecrit edilir (Tan vd., 2016, s. 2- 11).

Kan ve Tabu adlı çalışmasında Erginer (2003), menstrüasyon sürecine ilişkin tabuları şu şekilde yorumlamaktadir:

Antik Yunan'daki "şarap kızılı deniz", ayrıca

"Kız1l Deniz" de aynı sembolizme dayanır; ölüm ve yaşam rahimde birbirine karışır. Koyu kırmızı aynı zamanda hüznün rengidir. Kan kırmızısı, gizli olduğunda yaşamla, açı̆̆a çıktı̆̆ındaysa ölümle bağlantılıdır. Âdet gören kadınlara ilişkin tabular da bu ölüm düşüncesinden türemiştir. Âdet kanı kirlidir, çünkü rahmin karanlığından gün ışı̆̆ına çıktığında bu zıtlığın dengesini bozar. (s. 184)

Mac Enga topluluklarında erkeklerce gerçekleştirilen tüm işler kadınların kirleticiliğinin tehdidi altındadır. Erkek her şeyden önce âdet kanından korkar. Özellikle bozma büyüsünün olmadığı durumlarda âdet kanıyla ya da âdet olan kadınla temasta bulunmanın erkeği hasta edeceğine inanılır. Bu durumun erkekte devamlı kusmaya yol açacağına, onun kanını karartacağına, yaşamsal sıvılarını bozacağına, bu yüzden de derisinin koyulaşacağına, etinin çürüyüp cildinin kırışacağına, aklının sönükleşeceğine ve sonunda ağır bir çöküşe ve ölüme doğru yol alacağına inanılır (Douglas, 2017, s. 181-182).

Menstrüasyon tabuları kültürden kaynaklanır ve belirli bir kültürün algıları, tutumları, inançları ve değerlerine göre yorumlanır (Agyekum, 2002, s. 368). Çevresinde, pek çok sakınma ve kaçınma pratikleri geliştirilen menstrüasyon dönemi, geçici tabulara örnektir. Menstrüasyon dönemi ile cinsellik, doğurganlık ve kirlilik arasında ilişki kurulduğundan, bu dönem utanılacak ve saklanılacak bir dönem olarak algılanır. 
Genç kız sadece çevresinden değil, annesinden bile bu dönemi saklama eğilimindedir. Menstrüasyon olan bir kadın, sosyal ve ahlâkî yönden "tehlikeli ve kirli" olarak görülür ki, kanın tehlikeli etkileriyle ve kadınların saflı̆gıyla ilgili çeşitli sosyal normlar bu nedenle gelişmiştir (Rashid ve Michaud 2000, s. 65-66). Hindistan'da bir dizi efsane, tabu ve kısıtlama menstrüasyon dönemini çevreler. Birçok toplulukta ve ailede menstrüasyonla ilgili kültürel ve sosyal pratikler, din, kast, topluluk ve asırlık inançlar tarafindan yönlendirilir (Kumar ve Srivastava, 2011).

Abu-Lughod (2004, s. 153), kadınların, âdet döneminden kaynaklanan "doğal” kirlenme nedeniyle, toplum tarafindan ahlâkî olarak dindarllğa kolayca erişemeyecek kişiler olarak görüldüklerini vurgular. Menstrüasyon döneminde olan bir kadın kutsal mekânlara giremez çünkü bu evredeki bir kadın kirlidir, Menstrüasyon dönemindeki bir kadın "Mikvah" (abdest) olmadan kocasiyla ilişkiye girmemelidir, Menstrüasyon döneminde olan bir kadın kiliseye giremez, çünkü günahtır, Menstrüasyon döneminde olan bir kadın mezarlyğa giremez. Menstrüasyon dönemindeki bir kadınla ilişkiye giren erkek zührevi hastalık kapar. Menstrüasyon dönemindeki bir kadın temiz olmadığ1 için kocasıyla aynı yatakta yatmaz (Hand vd., 1981, s. 208-209).

Roma'lı Plinius'un Doğal Tarih’inde söylediklerine benzer batıl inançlar birçok kültürde bulunur: $\mathrm{Bu}$ kanla temas eden yeni yapılmış şarap sirkeye döner, mahsul bozulur, aşı tutmaz, bahçedeki tohum kurur, ağacın meyvesi düşer, çeliğin ucu körelir, fildişinin parlaklığı kaybolur, kovandaki anlar ölür, bronz ve demir bile paslanır, havayı korkunç bir koku kaplar; onu tadan köpek delirir, ısırdığ1 yer iltihap kapar ve iyileşmez. [...] Karınca gibi küçücük bir yaratığın bile ona karşı duyarlı olduğu ve onun bulaştığı mısır tanelerini taşımayı bırakıp, bir daha da dokunmadığ söylenir. (Direk, 2003, s. 253)

Menstrüasyon süreci sırasında sakınma, kaçınma, korunma ve korumaya yönelik geliştirilen uygulamalar ve yaşanacak herhangi bir olumsuzluk karşısında uygulanan sağaltma yöntemleri çevresinde geliştirilen büyüsel-dinsel içerikli pratiklerin çoğu bazı yörelerde canlılıklarını koruyarak sürdürülmektedir. Çalışmamızda, çok farklı inanç ve uygulamalarla yoğrulmuş zengin bir kültür birikimine sahip olan Şanlıurfa iline bağl1 Harran, Bozova ve Eyyübiye ilçelerinde menstrüasyon sürecine ilişkin, sakınma, kaçınma, korunma ve korumaya yönelik geliştirilen uygulamalar ve bu sürece ilişkin geliştirilen sağaltma yöntemleri üzerine odaklanılmış, elde edilen veriler nitel araştırma yöntemiyle yorumlanmıştır. Menstrüasyon kadınla ve kadınlıkla ilgili bir konudur ancak kültürel olarak sadece kadını ilgilendiren bir durum değildir, tüm toplumsal organizasyon ile yakından ilintilidir. Kadınların toplumsal hayatın çeșitli alanlarına erişiminin engellenmesine hatta izole edilmelerine vesile olur.

\section{Yöntem}

Çalışmamız alan araştırmasına dayanmaktadır ve derinlemesine görüşme tekniği uygulanmıştır. Çalışma, 2016 yılında Şanlıurfa iline bağlı Bozova, Eyyübiye ve Harran ilçelerinde, yaşları 18-73 arasında değişmekte olan 68 kadınla gerçekleştirilmiştir. Derinlemesine görüşme, öncelikle antropolojinin veri toplama tekniklerinden biridir. Günümüzde diğer sosyal bilim dallarında da kullanılan bu teknik, araştırmacının alan çalışmasında ayrıntılı ve derinlemesine bir biçimde konuyu kavramasina yarayacak bir araçtır (Kümbetoğlu, 2015, s. 71-72).

Bu çalışmadan çok daha önce 2005-2009 yılları arasında ve 2012 yilında araştırmacı belirli aralıklarla araştırma alanında bulunmuştur. Araştırma sürecine etkisi olan bu durum, bilgi kaynaklarına ulaşmadaki kolaylı̆̆1, günlük yaşam aktivitelerine ve bu çerçevede geliştirilen davranış kalıpları ile değerler sistemine aşinalığ1 sağlamıştır. Araştırma alanında bulunulan zamanlarda katılımlı gözlem tekniği de çoğu zaman uygulanmıştır.

Katılarak gözlemde araştırmacı, topluluğun bulunduğu yerde veya mekânda daima bulunmaya çaba gösterir; sosyal etkinliklere olabildiğince katılır ve sürekli gözlem yapma hâlinin yanı sıra sohbetlerle alan ilgisini elde eder. Katılarak gözlem "orada/alanda" olmaktır ve dışarıdan bakışın farkındalığıyla "içeride" yaşanan bakış açısını yakalamaya ve anlamaya çalışmaktır (Spradley vd.'den akt. Harmanşah ve Nahya, 2016, s. 22). Alan araştırması gözlem, görüşme, anket gibi pek çok unsuru içerse de öncelikle orada/alanda olmay1 (being there) ve gündelik yaşama katılımı ifade eder. Alan araştırması, toplumsal ilişkilerin ya da süreçlerin akışını yakından inceleme ve anlama olanaklarını sunar (Harmanşah ve Nahya, 2016, s. 17-30).

Çalışmamızda görüşmeler, bahsettiğimiz ilçelerde yaşayan 68 kadınla kendi evlerinde gerçekleştirilmiştir. Görüssme yaptığımız 68 kadının 67'si evlidir. Bekar olan 1 kadın 23 yaşında ve henüz boşanmıştır. Kadınların büyük çoğunluğu görücü usulü ile evlenmişlerdir. Kadinlar arasinda okuma yazma bilmeyenlerin sayisı 8'dir. 8 kadından 5'i hem Türkçe hem de okuma yazma bilmemektedir, bunlardan 3'ü etnik kökenlerini Arap diğerleri ise Kürt olarak belirtmişlerdir. Bu 5 kadınla 
görüşmelerimiz sırasında, kadınların Türkçe bilen, yakın yerlerde oturan kızları (çoğu aynı sokakta oturuyorlardı ve akraba evliliği yapmışlardı) ve aynı hane içinde yaşadıkları gelinleri, Arapça ve Kürtçe bilmememizden kaynaklanan iletişim sorunlarının çözümünde aktif rol oynamıslardır. Menstrüasyon sürecine ilişkin, sakınma, kaçınma, korunma ve korumaya yönelik geliștirilen uygulamalar ile bu sürece ilişkin geliştirilen sağaltma yöntemleri özellikle Eyyübiye ilçesinde yaşayan kadınlar tarafından ayrıntılı bir şekilde anlatılmıştır. Harran'da görüşülen kadınların çoğunluğu bu konuya ilişkin ayrıntılı bilgi vermekten kaçınmışlardır. Menstrüasyon sürecine ilişkin geliştirilen inanç ve pratiklerin neler olduğuna ilişkin anlatılar, kadınların sakınma, kaçınma, koruma ve korunmaya ilişkin kendilerince dikkatle uyguladıkları pratikler ve bu çerçevede geliştirilen inançları içermektedir. Kadınların deneyimleri, menstrüasyon ve kadınlık inșaları, bizzat onların söylem ve pratiklerine yer verilerek daha ayrıntılı bir şekilde araştırılmıştır. Kadınlar tarafından aktarılanlara ilişkin olarak bu çalıșmada menstrüasyon süreci ile ilgili bir takım toplumsal rol ve kabullere uymakla yükümlü kılınan kadınların, benimsedikleri kadınlık durumları ve pratiklerine bakılması amaçlanmaktadır. Bu bağlamda, Bozova, Eyyübiye ve Harran'da menstrüasyon süreci ile ilgili olarak sakınma, kaçınma, korunma ve korumaya yönelik geliştirilen, kültürde yer edinerek buradan beslenen ve toplumsal kabul gören pratiklerin sürekliliği olduğu varsayımından hareket edilecektir. Buralarda yaşayan kadınlarla yapılan derinlemesine görüşmeler, menstrüasyon sürecindeki kadına nasıl bir anlam yükledikleri, menstrüasyon deneyimlerini nasil aktardikları, hangi tabulara ve bendensel pratiklere vurgu ypatıkları gibi sorulara cevap aranarak ayrıntılandırılmıştır.

\section{Bulgular \\ Menstrüasyon anlatıları}

Daha önce de belirtildiği gibi kadınların günlük yaşam aktivitelerini ve bedensel pratiklerini derinden etkileyen konulardan birisidir menstrüasyon. Sürece ilk defa adım atan genç kadınlara özellikle anne ya da ablaları tarafından çeşitli öğütler verilir ve birtakım duyguları ve bedensel teknikleri öğrenmeleri ve uygulamaları beklenir. Görüşmelerde kadınlar tarafından bu duruma getirilen yorumlar ve anlatılar aşağıda belirtilmiştir:

- Bir genç kız ilk ay hâli olduğunda, annesi tarafindan bu durumdan korkmaması öğütlenir ve sağ dizini üç defa öpmesi tembihlenir. İlk ay hâlini gören kız dizini üç defa öperse bu durumun şokunu üstünden atar. Allah korusun kız üstünden bu şoku atamazsa âdetten kesilir ve uzunca bir süre aybaşı olamaz. Aybaşı bitiminde ise kıza banyo yaptırılır ve bu banyoda hayız abdesti (gusûl abdesti) aldırılır. Kız banyoda şöyle der:
Dağlardaki geyik gibi,
Sulardaki balık gibi,
Pisliği attım, temizliği kaptım,
Pür-ü pak oldum.

K1z bundan sonraki her âdet bitiminde banyo yaparken, abdest alırken bunu söylemelidir. Bize annemiz öğretti, biz de kızlarımıza öğretiyoruz. (50 yaşında kadın/Eyyübiye)

- İlk ay hâli olan kızın yüzüne annesi tarafindan tokat atılırsa kız şoktan kurtulur. Böylece kız hayatın şoklarına hazırlanır. Bir genç kız aybaşı olmaya başladığında, annesi kızın yüzüne tokat atarak kızını yaşama ve onun şoklarına hazırlar. (30 yaşında kadın/ Eyyübiye)

- Ay hâli olan kızın yüzüne tokat atılırsa, bunun kıza iyi şans getireceğine inanılır, Annesi yüzüne tokat atarsa, k1z hayat1 boyunca âdet dönemlerini rahat geçirir. (53 yaşında kadın/ Harran)

- Bir genç kız ay hâli olmaya başladığında, utançtan solan yüzüne kan gelmesi için tokat atılır. (45 yaşında kadın/Eyyübiye)

- İlk âdet olan kıza çok fazla sancilanmaması için soğuk taşa oturmaması, soğuk betona ayakları çıplak basmaması tembihlenir. Soğuk bir şey yerse ya da içerse, saçlarını yıkarsa sancılanır, tüm bunları yapmaması söylenir. (52 yaşında kadın/Bozova).

- İlk defa aybaşı olan kızı annesi ya da evde büyük kim varsa bahçeye çıkarır ve gördüğü ağaçları saydırır. Eğer kız bunu yaparsa bundan sonraki aybaşı günleri çok uzamaz, bu kıza iyi gelir. (43 yaşında kadın/Eyyübiye)

- İlk defa aybaşı olan kıza temizlikle, sağlıkla ilgili ve dinî açıdan neler yapması gerektiği söylenir. Artık bir genç kız olduğu için hâl ve hareketlerine dikkat etmesi gerektiği, sokakta oyun oynamaması gerektiği anlatılır. (35 yaşında kadın/Eyyübiye)

\section{Menstrüasyon süreci ile ilgili çeşitli pratikler}

Menstrüasyon sürecindeki bir kadının yapmaya çalışacağ çoğu şeyin başarısızlıkla sonuçlanacağına dair inanç kadınların neredeyse tamamında bulunmaktadır. Curtis (1981, s. 710), menstrüasyon dönemindeki kadınların başarı ve başarısızlık durumunda verdikleri tepkilerin daha yoğun olabileceğini; fakat kadının performansının menstrüasyon döneminde düştüğüne dair kesin bir verinin olmadığını, böyle bir yargının sadece kültürel bir beklenti olduğunu vurgular. 50 yaşındaki bir kadın bu dönemde kadınların neye dokunsa bozulacağını ya da ne yapmak isterse sonunun kötü olacağını söylemiştir. Örneğin: 
- Âdetli kadın hamur yoğurursa hamur çürür ya da hamurun tadı bozuk olur. (50 yaşında kadın/ Eyyübiye)

- Aybaşı dönemindeki bir kadının göğüslerini tutmak, kadının âdetinin kesilmesine neden olur. (45 yaşında kadın/Eyyübiye)

- Aybaşı dönemi ay tarafindan kontrol edilir. (60 yaşında kadın/Bozova)

Geciken aybaşını başlatmak için kaynar suyun buharına oturulur. Bu dönemindeki bir kadın soğuk şeyler yer veya içerse, kan donar ve akmaz. Bu dönemindeki bir kadın domates suyu, portakal suyu, limonata içerse kanın akışı durur. Aybaşı dönemindeki bir kadın banyo yaparsa kanın akışı kesilir.

Aybaşı döneminde olan bir genç kızın sararmasını önlemek için kız, içinde limon bulunan hiçbir şey yememeli ve içmemelidir.

- Aybaşı döneminde olan bir genç kız, hoplayıp zıplamamalıdır, çünkü bu zararlı olabilir

- Biz küçükken köyde aybaşı döneminde olan kız ata bindirilmezdi. Çünkü at, kanın kokusunu alır ve huysuzlandığı için zapt edilmesi zor olurdu. (35 yaşında kadın/Bozova)

- Aybaşı bir genç kız saçını yaptırırsa, saç tutmaz, bozulur, ayrıca âdetliyken saçını kestirmemelidir. (42 yaşında kadın/Bozova)

- Âdetli kadın turşuya, salamura bakarsa, yaklaşırsa, turşu kurarsa, o turşu ya da salamur bozulur, kötü kokar, turşunun üstü beyaz pamuk pamuk olur. (55 yaşında kadın/Eyyübiye)

- Âdet kanı bulaşan hiçbir şey yakılmamalıdır, eğer yakılırsa bu kadını tüketebilir. (47 yaşında kadın / Eyyübiye)

- Âdet kanı zehirleyicidir.

- Âdetli kadın çok fazla "kötü" kan atar. Eğer kadın üşütmüşse, kan ile birlikte zehir de atar.

- Bu dönemdeki bir kadın vücudunun herhangi bir yerinden kıl almamalıdır. Çünkü bu dönemde canı daha çok yanar. Bu dönemde saç ve tırnak kesilmez.

\section{Sakınma, kaçınma ve korunma}

Menstrual dönemdeki kadının kirli olduğu ve bu kirlenmeden dolayı tehlike içerdiğine olan inanç pek çok kültürde görülmektedir. Das (2008, s. 30), saflı̆gın aksine kirliliğin bir denge durumunu bozabileceğini, arzu edilen sınırları yok edebileceğini veya istenmeyen koşullara yol açabileceğine değinir. Hinduizm'de âdet kanaması, kir ve kir içeren kirletici bir madde görevi görür (Das, 2008, s. 30). Bu kadınları çok eski zamanlardan beri ikincil bir konuma sokar. Menstrüal algılar kadının gücünün sınırlandırılması ve aşağılanması eksenindedir (Das, 2008, s. 30). Araştırma alanımız içinde de görüştüğümüz kadınların neredeyse tamamına yakını âdetli kadının kirli olduğunu, temiz olmadığını, bu yüzden de âdetli kadının pek çok şeye dokunmaması gerektiğini, koktuğunu ve bu kokunun etrafı kirlettiğini, bu yüzden yeni doğmuş bebeklerin ve lohusa kadınların hastalanabileceklerini, bitkilerin kuruyacağını belirtmişlerdir. Menstrüasyon dönemindeki bir kadının "temiz olmadığı ve tehlikeli olduğuna" ilişkin örnekler ve yasaklar şöyle sıralanabilir:

- Aybaşı olan bir kadın, henüz kırkı çıkmamıs bir bebeği ve annesini görmemelidir. Buna engel olmak gerekir. "Onların yanına kırk gün boyunca melekler iniyor, kalkıyor, eğer o kadın yanlarına gelirse melekler bir daha gelmez, hem çok günahtır, çocukta annede hasta olur". (Vargün, 2018, s. 876) Âdetli iken yakınlık derecesi ne olursa olsun hiçbir kadın kırkı çıkmamış bebek ve anneyi ziyaret etmez, yanına yaklaşmaz. Âdetli kadın kesinlikle anneye de bebeğe de yaklaşmamalıdır. (58 yaşında kadın/ Eyyübiye)

- 27 yaşında olduğunu belirten bir kadın, lohusa kadın ve bebeğini âdetli kadından korumak için uygulanan sakınma ve kaçınma yöntemlerini anlatırken, âdet gören kadının pis ve tehlikeli olduğunu, koktuğunu, yaklaştığı anne ve bebeği hasta edeceğini belirtmiştir. Kadına göre âdetli kadın kirlidir. (27 yaşında kadın/ Eyyübiye)

- Ay hâlindeki kadın eğer yeni doğan çocuğu kucağına alırsa, çocuğa kötü ruhlar musallat olur ve çocuk artık iflah olmaz, belki hiç konuşamaz, belki çok geç konuşur, lohusa kadın ise hastalanır. Bundan dolayı âdetli kadın anne ve çocuğa yaklaştırılmaz (Vargün, 2018, s. 877), eğer durumu biliniyorsa yaklaşmamas1 için uyarılır. (60 yaşında kadın/Bozova)

- Ay hâlindeki bir genç kız, asla bir oğlanın kendisine dokunmasina izin vermemelidir. Bir erkek asla âdetli bir kadına dokunmamalıdır, yoksa "kirlenir". (37 yaşında kadın/Bozova)

- Aybaşı olan bir genç kız, hastalığı bittiğinde hemen yıkanmalı, üstünden kiri atmalıdır. (45 yaşında kadın/ Eyyübiye)

- Âdet gören kadın kocasıyla birlikte olamaz, kocası ssrar da etse günahtır olmaz. Kadın kocasına bunun anasiyla, bacisıyla olmuş gibi günah olduğunu hatırlatmalıdır. (60 yaşında kadın/Eyyübiye).

- Eğer bir genç kızın sesi konuşurken çatallı çıkıyorsa, bu onun aybaşı olduğunun işaretidir. Kızı mutfaktan uzak tutmak gerekir (aybaşı olan bir kadın ya da genç kız mutfakta bir şeyler yaparsa mutfağın bereketi kalmaz, yiyecekler bozulur), evde lohusa bir kadın ve kırkı çıkmamış bebek varsa, kız onların yanına asla girmemelidir. Bebeğin yüzüne bakmamalıdır. Yıkanana kadar onlardan uzak durmalıdır. (60 yaşında kadın / Eyyübiye) 
- $\mathrm{Bu}$ dönemde hiçbir ibadet yapılmaz. Kanama bittikten sonra gusûl abdesti alınmalıdır. (47 yaşında kadın/Harran)

- Bu dönemde saç kesilmez, dua edilmez, mezarlı̆ga girilmez. Âdetliyken ibadet yapılmaz. (55 yaşında kadin/Bozova)

- Âdet bitince boy abdesti alınır. Bu dönemde Kur-an okunmaz, ama dinlenebilir. Kadın, kocasıyla ilişkiye giremez. (32 yaşında kadın/ Eyyübiye)

- Kanlı bezler âdet bitince hemen yıkanmalıdır, bekletilmemelidir. Ped kullanıliyorsa (burada görüşmeci ped yerine bilinen bir markanın ismini kullanmıştır) kanı iyice akıtılmadan sobaya atılıp yakılmamalıdır. Çok günah olur. (45 yaşında kadın/ Eyyübiye)

- Turşu kurulmaz, turşunun başına gidilmez, turşu çıkartılmaz. Bu dönemde hamur yoğrulmaz, ekmek yapılmaz, çünkü pis olunur. Hamur yoğrulmaz, çünkü bu dönemde kadının elleri daha çok terler. Konserve kapağı açılmaz, çünkü içindeki yiyecek bozulur. (58 yaşında kadın/Eyyübiye)

- $\mathrm{Bu}$ dönemde kırkı çıkmamış çocuğun yanına girilmez, çünkü bu dönemde kadınlar çok terlerler ve vücutlarından kötü kokulu, mikroplu ter atarlar. Yeni doğmuş çocuğun bulunduğu odanın havasını kirletirler ve çocuk hasta olur. (40 yaşında kadın/ Eyyübiye)

- Âdet döneminde bitki dikemezsin, tutmaz. Yeni doğan bebeğin yüzüne bakamazsın, çünkü sarllık olur. (55 yaşında kadın/Bozova)

- Kırkı çıkmamıș bebek aybașı olan kadına gösterilmez. Âdetli kadın çocuğun yüzüne bakarsa o çocuk hasta olur, yüzü çiçek döküğü gibi olur. (44 yaşında kadın/Eyyübiye)

- Âdetliyken yoğurt mayalanmaz ya da yeni tutmuş yoğurt açılmaz çünkü bozulur. (34 yaşında kadın/ Harran)

- Âdetliyken kek yaparsan kabarmaz, hamur yoğurursan hamur çürür. (Şanlıurfa Merkez'de yaşayan, ziyaret için Harran'da bulunan 36 yaşında kadin)

\section{Tartışma}

Kadınların günlük yaşam aktivitelerini derinden etkileyen bir durum olan mentrüasyon süreci, biyolojik ve fizyolojik bir durum olmasının yanı sıra kültürel de bir durumdur. $\mathrm{Bu}$ makalede, kadınların menstrüasyon sürecine ilişkin benimsedikleri bedensel pratiklere dikkat çekilerek, menstrüasyon ve kirlilik algısının kadınlar tarafindan nasıl yorumlandığına, tecrübe edildiğine odaklanılmıştır. Ayrıca menstrüasyon dönemindeki kadınların toplumsal olarak hareket alanlarının ve hareket serbestliklerinin kısıtlandığına değinilmiştir. Menstrüasyon sürecinde kadın, gündelik yaşam pratikleri içerisinde, sakınma ve kaçınma hâli içerisindedir. Bu süreçte kadının kirlilik ve pislik algısı kendi menstrüasyon süreci ile ilgilidir ve buradaki kirlilik algısı kadınlığa ilişkin aktarılan öğretilerle hem duygusal hem de bedensel pratikler olarak içselleştirilmektedir. Fizyolojik bir durum olan menstrüasyon sürecinde kadın cinsiyetçi ritüeller, kurallar ve tabular aracılığıyla çevrelenir ve kontrol edilir. Örneğin menstrüasyon sürecindeki kadının mutfak aktivitelerinden uzak durmaya çalışması, ilk regl döneminden sonra statü ve rollerdeki değişim, genç bir kız olarak belirli davranış kurallarına uyma zorunluluğu, menstrüasyon sürecini yaşadığına dair ibarelerin anlaşılmaması ve hatta bu durumun konuşulmasının utanç verici bir durum olarak algılanmasından dolayı çeşitli stratejiler geliştirmesi gerekir.

Connell'e (2019) göre, , toplumsal pratikler, doğal farklılıkları büyük ölçüde abartarak veya çarpıtarak etraflarinda bir sembol ve yorum yapisı örerler. Toplumsal cinsiyete ilişkin toplumsal düzenlemeleri ayrıntılarıyla incelemeye kalktığımızda yadsımaların, dönüşümlerin ve çelişkilerin ne kadar düzenli bir şekilde ortaya çıktıkları ise çok çarpıcıdır. Aşkın pratikte "yeni bir olgunun" yaratılması hiçbir şekilde bedeni, üreme biyolojisini, bedensel farklılığ1 veya fiziksel deneyimi dışlamaz. Bu bağlantının yitirilmesi ataerkil ideolojinin âdet görmeyi utanç verici ve ağza alınamaz olarak tanımlayıp kadınların deneyiminin bir kısmını dilden dışladığında söz konusu olan bastırma biçiminin yaratilmas1 olacaktır (Connell, 2019, s. 127-131).

Menstrüal dönemdeki bir kadının, kendisine yüklenen kadınlık rolleri çerçevesinde, içinde bulunulan kültüre ait uygun davranış kalıplarını benimsemesi ve sergilemesi beklenir. Bireyler, bedenlileşme teorilerinde ima edilen bedenselliğin sonucunda, toplumsal olarak öğrenilen; doğurma, âdet görme ve temizlenmek gibi biyolojik, fizyolojik bir takım genel pratikleri (Aksoy Sugiyama, 2010, s. 78) farklı nüanslar, bazen de farklı stratejileri devreye sokarak hayatları boyunca tekrarlarlar. Bu açıdan bakıldığında menstrüasyon, kaçınma, sakınma ve mahcubiyet ile çevrelenen ve bu duygulara göre davranışların hem öğrenildiği hem de geliştirildiği bir konudur. Direk (2003), menstrual dönem ve bu döneme ait tabuları şu şekilde ifade etmektedir:

Âdet kanamasıyla ilgili tabular, kültürel yasakların kadının doğa ile ilişkisini, tanrı ile ilişkisini, kamusal ve özel alanda ötekiyle ilişkisini sınırlayabildiğini ortaya koymaktadır. [...] Bizim kültürümüzde yaşayan kadının ruhunda bu yasakların ve dışlamanın bıraktığı iz utanç duygusunu üretir. Sözünü ettiğimiz/etmekte zorlandığımız kanama, 
toplumsal cinsiyetinde maddeleşmiş dişi vücudun utanılması, sakınılması gereken ikinci hayatına aittir. [...] Normal bir kanamayı durdurmak için kullanılan hiçbir malzemenin görünür olması, ortada dolaşması ayıp değilken, çeşitli kadın bağ1 ürünleri ve tamponlar gözlerden rrak tutulmalıdır. [...] Kültür, doğurganlıklarının işareti olan âdet kanamasını kadınlara nefret edilecek bir durum, bir ayıp, bir bela, bir lanet gibi yaşamayı öğretir. O günlerde kadınlar kanın giyside görünürlüğü korkusunu üstlerinde ikinci bir elbise gibi taşırlar. (Direk, 2003, s. 253-254)

Kültürel norm ve değerlere göre belirlenen bireyin kadin ve erkek olma gibi temel nitelikleri, kültürün kuşaktan kuşağa aktarımı ile kadınlık ve erkeklik normlarına uygun davranışlar sergilemelerini gerektirir. Bireye içine doğduğu kültür tarafindan kadınlık ve erkeklik normlarının aktarımı, tekrarlanan bir süreç olması nedeniyle, toplumsal cinsiyetin yeniden öğrenildiği ve üretildiğini de göstermektedir.

Yüksel'e (2001, s. 73) göre toplumsal cinsiyet kavramı, kadın ve erkek arasındaki toplumsal, kültürel, ekonomik, politik ve davranışsal tüm farklılıkları içerir. Bireyin kadın ya da erkek olma gibi temel bireysel niteliklerinin ve kişisel kanılarının toplumun kadınlık ve erkeklik normlarına uygun olmasi gerekmektedir. $\mathrm{Bu}$ normlar arasında, kadın ve erkeklik rolleri, kadın ve erkeğin kendini sunuş şekli, konuşması, davranış kalıpları, giyim kuşam kodları bulunmaktadır. Bu kalıp ve kodlamalar toplumdan topluma farkl1lık göstermektedir.

Birey için kültürel olarak erkek ya da kadın olmanın tanımı, toplumsal yapı tarafindan düzenlenmektedir:

Yeni doğan çocuğun biyolojik bir cinsiyeti vardır ama henüz toplumsal bir cinsiyete sahip değildir. Çocuğun öğrenmeye başlamasıyla beraber toplum, çocuğun önüne cinsiyetine uygun bir kurallar, şablonlar ya da davranış modelleri dizisi koyar. Belirli toplumsallaştırma etkenleri ya da failleri -özellikle aile medya, arkadaş grupları ve okul- söz konusu bu beklentileri ve modelleri somutlaştırarak çocuğun bunları sahipleneceği ortamları hazırlar. [...] Toplumsal modeller ya da kurallar ne olursa olsun, az ya da çok içselleştirilirler. Bunun sonucunda, normalde belirli bir cinsiyetin toplumsal beklentileriyle örtüşen toplumsal cinsiyet kimliği ortaya çıkar. (Connell, 2019, s. 278)

Demez (2005, s. 29), cinsiyetin biyolojik özelliklerinden bağımsız olarak kadın ve erkeğin toplumsal algılanışlarına ve kültürel olarak kadın ve erkek olma sürecine işaret eder ve toplumun, kadını ve erkeği tarihsel süreç içinde bazı alanlara ait kıldığına ve yaşanilan toplumsal yap1 ve dönemin, kadının ve erkeğin sosyal işlevlerini tanımladığına; kadın ve erkeğin görünürlüğ̈̈ ve değerinin kültür tarafindan belirtildiğine dikkat çeker.

Görüşmelerimiz sırasında kadınlar tarafindan ifade edilen "illk defa âdet gören kızın artık bir genç kız olduğu için hâl ve hareketlerine dikkat etmesi ve sokakta oyun oynamaması gerektiği” düşüncesi, kadınlık normlarına uygun davranışlar sergilenmesi öğretisinin bir göstergesi ve aynı zamanda tabunun toplumsal cinsiyetçi mekanları yaratmada kurucu rolünü gözler önüne sermektedir. det gören kız artık bir çocuk değildir, sokağa çıkamaz ve erkeklerin yanında hâl ve hareketlerine dikkat etmesi gerekir. "Evin dışı, sokak, kadının rahatça dolaşacağı, vakit geçireceği, üretime katılacağı bir yer değildir... Erkekler için ev, kadınlar için sokak kendilerini eğreti hissettikleri mekânlardır" (Yüksel, 2008, s. 132). Connell'e (2017) göre "sokak büyük bir erkeklik/kadınlık biçemleri ve cinsellik tiyatrosudur" (s. 199). Sokak, eril bir mekândır. Bu yüzdendir ki âdet gören kız artık sokakta oynayamaz. "Sokak, toplumsal cinsiyet farklılaşmasının kendini gösterdiği en önemli mekânlardandır" (Vargün, 2021, s. 318). Giddens (2008, s. 102), bir kez toplumsal cinsiyet yüklenildiğinde, toplumun bireylerden "kadınlar" ve "erkekler" olarak davranmalarını beklediğini ve bu beklentilerin yerine getirildiği ve yeniden üretildiği yerin, gündelik yaşamın pratikleri içinde olduğunu belirtir. Ancak şunu da göz önünde bulundurmak gerekir ki söylem olarak tabuların, beden tekniklerine ne oranda dönüşeceği, bireyden bireye farklılık gösterecektir. Bu anlamda etki alanları sabit değildir.

Menstrüasyon hem biyolojik hem de sosyal etkileri olan ve özellikle geleneksel uygulamaların ağır bastı̆̆1 toplumlarda kültürel şartlanma ve değerler çerçevesinde yaşanan bir süreçtir. Yeni âdet gören bir kadına açılanan ve ondan beklenen kadınlık bilincini geliştirmektir (Das, 2001, s. 32-37)

Çalışmamızda, Şanlıurfa iline bağlı Harran, Bozova ve Eyyübiye ilçelerinde menstrüasyon sürecine ilişkin, sakınma, kaçınma, korunma ve korumaya yönelik geliştirilen uygulamalar ile bu sürece ilişkin geliştirilen sağaltma yöntemleri üzerine odaklanılmıştır. Menstrüal dönem ile ilgili sakınma, kaçınma, korunma ve korumaya yönelik geliştirilen uygulamalar ve sağaltma yöntemleri 
ile büyüsel-dinsel içerikli pratiklerin çoğunun iç içe geçtiği gözlenmiştir.

Menstrüasyon dönemiyle ilgili tabulara bakıldığında, kadınların toplumsal olarak hareket alanlarının ve hareket serbestliklerinin kısıtlandığını görürüz. Hareket serbestliğinin kisıtlanmasının nedenleri, kendilerine aktarılan ve içselleştirilen kadınlık rol ve beklentileridir. Kadınların ve genç kızların bu süreçte fiziksel olarak kendi eylemlerini kısıtlama eğiliminde oldukları ve daha çok temizlik, kirlilik, tehlike, günah konuları üzerinde yoğunlaştıkları gözlenmektedir. Menstrüasyonla ilgili tabular, sözel olarak kuşaktan kuşağa aktarılmaktadır. Kadınlar ve genç kızlar sakınma, kaçınma, korumaya ilişskin toplumun değer yargılarından ve beklentilerinden etkilenmekte ve çoğunlukla uyum göstermektedirler. Menstrüasyon dönemindeki kadının yaşadığı alanın ve yaptığ1 şeylerin kısıtlı oluşuyla ilgili verilen örnekler genellikle sakınma, kaçınma ve korumaya yöneliktir. Lohusa kadın ve kırkı çıkmamış bebeğin sakınılması uygulamasında olduğu gibi sakınılması gereken kadının kendisi bir çeşit tabuya dönüşmüş gibidir. Kadınlar, menstrüasyon süreci ile ilgili geliştirilen uygulama ve inançları çoğunlukla bir önceki kuşaktan özellikle annelerinden öğrenmekte ve kabullenmektedirler. Menstrüasyon çevresinde geliştirilen pratikler "kadına özgü, cinsiyet ayrımının sembolü olarak görülebilir" (Das, 2011, s. 32).

\section{Sonuç}

Özellikle kültürel hafizanın aktarımında kadınlar başat bir role sahiplerdir ve bu uygulamaları kuşaktan kuşağa aktararak günlük yaşam aktivitelerinin düzenlenmesini sağlamak, onların birincil görevi olmuştur. Menstrüasyon dönemi kadınlar için saklanması gereken, utanç yaratan bir durum olarak algilanmakta ve bu durum kültürel olarak hissettirilmektedir. Menstrüasyon sürecindeki kadının bu dönemde hasta ve tehlikeli olduğunu ve yapacağ1 şeylerin de bundan olumsuz etkileneceğini düşünenler, sadece kadının çevresi değildir, aynı zamanda kadının kendisi de buna inanmış görünmektedir. Bu dönemle ilgili önlemler, yapılması ve yapılmaması gereken şeyler o kadar çoktur ki, menstrüasyon dönemi, kadın için açıkça bir "inzivaya çekilme” dönemidir; zaten kültürel beklenti de bu yöndedir ve kadın bu beklentilere göre yönlenir. Menstrüasyon sürecindeki kadın ailesi ve çevresi için bir tehlike kaynağ1 durumunda olduğu için çok fazla ölçülü davranmalı ve olabildiğince mutfak aktivitelerinde olduğu gibi, pek çok aktiviteden de uzak durmalıdır. Menstrüasyon sürecindeki kadının ikili bir yönü vardır. Bu ikili yön kadının bir taraftan tehlikeye açık olması, diğer taraftan tehlikenin kaynağı olarak görülmesi durumudur. Bundan dolayıdır ki kadının ilk menstrüasyonunda dinsel büyüsel içerikli çeşitli koruyucu önlemler alınmaktadır. İlk defa menstrüasyon sürecine giren kızın şoka girmemesi, şoka girmesinden dolayı âdetten kesilmemesi, aşırı sancılanmaması için bir dizi önlemlerin alınması, buna karşılık mutfak aktivitelerinden, kırkı çıkmamış bebekten, lohusa kadindan, erkeklerden, yeni ekilen tarladan vb. uzak durması, bu süreçte bir tehlike kaynağ1 olarak görülmesinden kaynaklanmaktadır. Menstrüasyon sürecindeki kadının neleri yapıp, neleri yapmaması gerektiğine dair verilen öğütlerin tümü kadının ilk menstrüasyonunda tehlikeye açıllı̆ıını daha sonraki menstrüasyon süreçlerinde ise tehlikenin kaynağ1 olarak nitelendiğini göstermektedir.

Genel olarak baktığımızda kadın ya da erkek olmanın tanımı kültür tarafindan belirlenmekte, aktarılarak sürdürülmekte ve yeniden üretilmektedir. Menstrüasyon sürecine ilişkin pratiklerin ve uygulamaların incelenmesiyle toplum içinde kadınlığın nasıl tanımlandığı, bu bağlamda bu sürecin yaşanışına ilişkin, kültürel kabul ve redlerin neler olduğu, nasıl tanımlandığı, bu sürece ilişkin uygulama ve pratiklerin aktarımı incelenmiştir. Menstrüasyon kadınla, kadınlıkla ilgili bir konudur ancak kültürel olarak sadece kadını ilgilendiren bir durum değildir. Bu bağlamda bu sürecin yaşanımlanışına ilişkin elde ettiğimiz veriler, kültürel değer ve pratikleri göstermesi açısından önemlidir.

\section{Kaynakça}

Abu-Lughod, L. (2004). Peçeli duygular. Epsilon Yayınları.

Agyekum, K. (2002). Menstruation as a verbal taboo among the Akan of Ghana. Journal of Anthropological Research, 58(3), 367-387. https://doi.org/10.1086/jar.58.3.3631182

Aksoy Sugiyama, C. (2010). Antropolojide beden sorunsalına bedenlileşme teorisinin katkıs1. Antropoloji, 24, 69-93. https://doi.org/10.1501/antro 0000000020

Connell, R. W. (2019). Toplumsal cinsiyet ve iktidar: Toplum, kişi ve cinsel politika. Ayrıntı Yayınları.

Curtis, R. (1981). Success and failure, gender differences and the menstrual cycle. Psychology of Women Quarterly, 5(5), 702-710. https://doi.org/10.1177/036168438100505s06

Das, M. (2008). Menstruation as pollution: Taboos in Simlitola, Assam, Indian Anthropologist, 38(2), 29-42. https://www. jstor.org/stable/41920072

Demez, G. (2005). Kabadayıdan sanal delikanlyya değģşen erkek imgesi. Babil Yayınları.

Direk, Z. (2003). Adet kanaması tecrübesi: Sinırlar ve ufuklar. Cogito, 37, 250-261.

Douglas, M. (2017). Saflke ve teblike: Kirlilik ve tabu kavramlarmm bir çözümlemesi. Metis Yayınları.

Erginer, G. (2003). Kan ve tabu. Cogito, 37, 181-191.

Faithorn, E. (2014). Papua Yeni Gine dağlarındaki Kafe'lerde kirlilik kavramı. R. R. Reiter (Ed.) içinde, Kadın Antropolojisi (s. 137-152). Dipnot Yayınları.

Freud, S. (2014). Totem ve tabu. Sosyal Yayınları. 
Giddens, A. (2008). Sosyoloji. Kırmız1 Yayınları.

Gould, J., ve Kolb, W. (Ed.) (1964). A dictionary of the social sciences. Tavistock Publications.

Hand, W. D., Casetta A., ve Thiederman S. B. (1981). Popular beliefs and superstitions. - A compendium of American folklore - I. G. K. Hall and Company.

Hand, W. D., Casetta A., ve Thiederman S. B. (1981). Popular beliefs and superstitions. - A compendium of American folklore - II. G. K. Hall and Company.

Hage, P., ve Frank H., (1981). Pollution beliefs in highland New Guinea. Man, 16(3), 367-375. https://doi. $\underline{\operatorname{org} / 10.2307 / 2801289}$

Harris, M. (1994). Yamyamlar ve krallar: Kültürlerin kökenleri. İmge Kitabevi Yayınları.

Harmanşah, R., ve Nahya, Z. N. (2016). Etnografik bikâyeler: Türkiye'de alan arastırması deneyimleri. Metis Yayınları.

Kumar, A., ve Srivastava, K. (2011). Cultural and social practices regarding menstruation among adolescent girls. Social Work. in Public Health, 26(6), 594-604. https://doi.org/10.1080/1 $\underline{9371918.2010 .525144}$

Kümbetoğlu, B. (2015). Sosyolojide ve antropolojide niteliksel yöntem ve araștırma. Bağlam Yayınları.

Leach, M. (1972). Standart dictionary of folklore, mythology and legend. Funk and Wagnalls.

Örnek, S. V. (1995). 100 soruda ilkellerde din büyü sanat efsane. Gerçek Yayınevi.

Rashid, S. F., ve Michaud, S. (2000). Female adolescents and their sexuality: Notions of honour, shame, purity and pollution during the floods. Disasters, 24(1), 54-70. https://doi. org/10.1111/1467-7717.00131

Tan, D. A., Haththotuwa, R., ve Fraser, J. S. (2016). Cultural aspects and mythologies surrounding menstruation and abnormal uterine bleeding. Best Practice \& Research Clinical Obstetrics and Gynaecology, 40, 121-133. https://doi.org/10.1016/j. bpobgyn.2016.09.015

Thompson, S. (1966). Motif-Index of folk-literature - I (A-C). Indiana University Press.

Türk, H. (2013). Anadolu'nun giz̨li inancı. Nusayrîlik: Inanç sistemleri ve kültürel özellikeleri. Kaknüs Yayınları.

Türk, H., ve Avşar, H. (2008). Illkel ve geleneksel toplumlarda cinsiyet, cinsellik ve tabu. İstanbul Üniversitesi İletişim Fakültesi Yayınları.

Underhill, R. M. (2003). Papago kadın - Arizona çöllerinde bir Kı̨̧lderili. Epsilon Yayınları.

Vargün, B. (2018). Doğum ve doğum sonrasında anne ve bebeğin korunmasına ilișkin geleneksel uygulamalar. International Journal of Human Sciences, 15(2), 870-880. https://doi. org/10.14687/ihs.v15i2.5309

Vargün, B. (2021). Cinsiyet farklılaştırması kadınlık ve erkeklik. H. Türk (Ed.) içinde, Kültür Kuramı ve Kavramı: Sosyal ve Kültürel Antropoloji (s. 309-324). Nobel Yayincilik.

Yüksel, N. A. (2001). Tarkan - Yıldı olgusu. Çivi Yazıları.

Yüksel Akıncı, N. A. (2008). Taşra, gelenek ve toplumsal cinsiyet: Dar alanda kısa paslaşmalar. Selçuk Üniversitesi İletişim Fakültesi Akademik Dergisi, 5(2), 128-135. https://dergipark. org.tr/en/pub/josc/issue/19016/200709

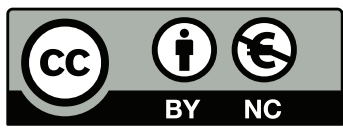

2021. Telif hakları yazar(lar)a aittir.

Bu makale Creative Commons Attf-GayriTicari 4.0 Uluslararası (CC BY-NC 4.0) lisansının hüküm ve şartları alında yayımlanan açık erişimli bir makaledir. 